\title{
Inhibitory Effects of some Fungicides against Macrophomina phaseolina Causing Charcoal Rot
}

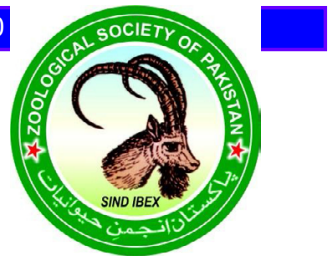

\author{
Umer Iqbal ${ }^{1, *}$ and Tariq Mukhtar \\ ${ }^{I}$ Crop Diseases Research Institute, National Agricultural Research Centre, Park Road, \\ Islamabad \\ ${ }^{2}$ Department of Plant Pathology, Pir Mehr Ali Shah Arid Agriculture University, Rawalpindi
}

\begin{abstract}
A B S T R A C T
No fungicides have been registered to control Macrophomina phaseolina in Pakistan. Therefore, in the present study, nine fungicides belonging to different groups were evaluated for their in vitro and in vivo effectiveness against $M$. phaseolina. Highly significant inhibitory effects of fungicides were recorded on the growth of $M$. phaseolina. All the fungicides caused significant inhibition of the fungus over control. Maximum individual inhibition of growth of the fungus was recorded with Benomyl (83.89\%) followed by Carbendazim $(79.11 \%)$ at a concentration of $150 \mathrm{ppm}$. Copper oxychloride at a concentration of 50 ppm gave the minimum inhibition (12.50\%). Concentrations also had significant inhibitory effects on the growth of the fungus. All the fungicides caused maximum inhibition of the growth of the fungus at a concentration of $150 \mathrm{ppm}$. With a decrease in the concentration, the inhibition in the growth also decreased. The inhibition of growth was found to be directly proportional to the concentration. Fungicides also affected significantly the plant survival of green gram and black gram over control. Maximum plant survival was observed where the seeds were treated with Benomyl followed by Carbendazim. However, Copper + Mancozeb and Copper oxychloride treated seeds gave the minimum germination and survival of plants. Doses also had a significant effect on the germination and plant survival. Maximum germination and survival were recorded where the seeds were treated with a concentration of $150 \mathrm{ppm}$ and minimum was recorded in case of $50 \mathrm{ppm}$ concentration. With a decrease in the concentration, the germination and survival decreased significantly showing a direct relationship between concentrations and plant survival. Benomyl at $150 \mathrm{ppm}$ concentration showed the highest rate of plant survival of $76.67 \%$ whereas Carbendazim and Propineb with same concentration exhibited 66.67 and $63.33 \%$ plant survival respectively. Copper oxychloride proved to be the least effective.
\end{abstract}

\begin{tabular}{l} 
Article Information \\
Received 28 December 2018 \\
Revised 12 February 2019 \\
Accepted 15 March 2019 \\
Available online 28 January 2020 \\
Authors' Contribution \\
\hline UI designed the study, executed \\
experimental work, analyzed the data \\
and prepared the manuscript. TM \\
helped in designing the study and \\
supervised the experimental work. \\
Key words \\
Charcoal rot, Chemical control, \\
Fungicides, Growth inhibition, Plant \\
survival
\end{tabular}

\section{INTRODUCTION}

$\mathrm{P}$ ulses being important food stuff are used in different forms in almost all the tropical and subtropical countries and constitute an essential part of human diet. Pulses are rich in proteins (20-26\%), vitamins (A, B, C and niacin) and minerals (potassium, phosphorus and calcium) vital for human body (Malik, 1994). They are regarded as economically important in cropping systems to substitute expensive nitrogenous fertilizers by fixing atmospheric nitrogen through nitrogen fixing rhizobacteria which result in an increase in the fertility of soils.

Green gram (Vigna radiata L.) Wilczek. and black gram (Vigna mungo L.) Hepper are two important summer pulse crops of Pakistan, cultivated on an area of 245.9 and 32.5 thousand hectares with a total production of 177.7 and

\footnotetext{
* Corresponding author: umer_iqbal2003@yahoo.com 0030-9923/2020/0002-0709 \$ 9.00/0

Copyright 2020 Zoological Society of Pakistan
}

17.3 thousand tons respectively (Anonymous, 2011) under a wide range of agro ecological zones. The average yields of these pulses in Pakistan are very low as compared to their potential yields obtained in many other countries of the world. Legions of biotic and abiotic factors are responsible for this low yield. Among biotic factors, diseases are the most destructive (Ashfaq et al., 2017; Aslam et al., 2017a, b, 2019a, b; Fateh et al., 2017; Javed et al., 2017a, b: Kayani et al., 2017; Khan et al., 2017; Mukhtar et al., 2017a, b, 2018; Kayani and Mukhtar, 2018; Mukhtar, 2018; Tariq-Khan et al., 2017). Up to 44 percent yield losses to pulse crops have been reported due to diseases, depending upon the crop variety (Bashir and Malik, 1988). Green gram and black gram are invaded by about 26 diseases in the world (Charles, 1978); charcoal rot incited by Macrophomina phaseolina (Tassi) Goid, is of prime significance in reducing crop yield especially in arid regions of the world (Hoes, 1985; Iqbal and Mukhtar, 2014; Iqbal et al., 2014). The pathogen is distributed all over the world in diverse climatic conditions from arid to 
tropical regions. It has a broad host range (Cottingham, 1981; Abawi and Pastor-Corrales, 1990) infecting more than 500 hosts including legumes and cereals (Dhingra and Chagas, 1981; Sinclair, 1982).

M. phaseolina is a soil and seed borne pathogenic fungus and produces cushion shaped black sclerotia (Wheeler, 1975) and disease severity is correlated with viable sclerotia present in the soil. All the growth stages of plants are infected by charcoal rot. The disease manifests in the form of dark lesions on the epicotyls and hypocotyls resulting in seedling death due to occlusion of xylem vessels. The pathogen causes red to brown lesions on roots and stems, produces dark mycelia and black microsclerotia. Severe infections cause defoliation and wilting (Abawi and Pastor-Corrales, 1990) resulting in $100 \%$ yield losses (Bashir and Malik, 1988). Due to lack of resistant cultivars in the country, non availability of commercialized biological control agents and the associated problems in their use, management of charcoal rot is mainly relied on synthetic fungicides. In Pakistan no fungicides have been registered for the management of charcoal rot of green gram and black gram. Mostly, the fungicides labeled to control other soil borne pathogens are currently used to manage this disease which do not give satisfactory control. For these reasons, in the present study, nine fungicides belonging to different groups were evaluated for their in vitro and in vivo effectiveness against $M$. phaseolina with the objective to identify some new fungicides to update disease management strategies.

\section{MATERIALS AND METHODS}

Isolation, purification and identification of $\mathrm{M}$. phaseolina

The fungus used in the study was isolated from stem bark tissues of black gram bearing fungal sclerotia and characteristic charcoal rot symptoms. The samples were cut into small pieces $(5-10 \mathrm{~mm}$ long), surface sterilized with $1 \%$ sodium hypochlorite for 2 minutes and then rinsed thrice in sterilized distilled water. The pieces were placed on Chloroneb Mercury Rose Bengal Agar (CMRA) medium (Meyer et al., 1973) in Petri dishes and incubated in dark at $25 \pm 1^{\circ} \mathrm{C}$ for 7 days. A small portion of the actively growing colony of $M$. phaseolina was taken from the periphery of $90 \mathrm{~mm}$ diameter Petri dish and spread onto Petri dishes containing glucose agar medium (glucose, 20 $\mathrm{g}$; agar, $20 \mathrm{~g}$ and water, $1000 \mathrm{ml}$ ) and incubated in dark at $25 \pm 1^{\circ} \mathrm{C}$ for 7 days. A small portion of the colony having sclerotia was taken into a drop of sterilized water and agitated with a sterilized needle to separate the sclerotia from the mycelia. Sclerotia were then transferred to 90 mm diameter Petri dishes containing CMRA medium. Colonies appearing from single sclerotium were again transferred to CMRA medium in $90 \mathrm{~mm}$ Petri plates, incubated as mentioned above and identified on the basis of standard key (Barnett and Hunter, 1972).

Multiplication of M. phaseolina for pot assay

Sorghum seeds were water soaked overnight, air dried under room temperature and placed in conical flasks. The mouth of each flask was plugged with cotton wool, wrapped in aluminum foil and autoclaved at $15 \mathrm{psi}$ $\left(121^{\circ} \mathrm{C}\right)$ for 20 minutes. After cooling, the seeds in flasks were inoculated with $4 \mathrm{~mm}$ mycelial plugs from a 7-day old culture of M. phaseolina and incubated at $25 \pm 1{ }^{\circ} \mathrm{C}$ for 15 days. The flasks were shaken at alternate days for uniform colonization of the grains. The inoculum thus produced was used in pot experiments.

Evaluation of fungicides for their effectiveness against $\mathrm{M}$. phaseolina

Nine fungicides (Table I) were tested for their effectiveness against $M$. phaseolina in vitro and in pot culture assay.

Table I.- Fungicides evaluated for their effectiveness against charcoal rot fungus.

\begin{tabular}{|c|c|c|c|c|}
\hline $\begin{array}{l}\text { Sr. } \\
\text { No. }\end{array}$ & Fungicide & $\begin{array}{l}\text { Chemical } \\
\text { name }\end{array}$ & $\begin{array}{l}\text { Formu- } \\
\text { lation }\end{array}$ & $\begin{array}{l}\text { Manufac- } \\
\text { turer }\end{array}$ \\
\hline 1 & Antracol & Propineb & $70 \mathrm{WP}$ & $\begin{array}{l}\text { Bayer (Pvt) } \\
\text { Ltd. }\end{array}$ \\
\hline 2 & $\begin{array}{l}\text { Trimiltox } \\
\text { Forte }\end{array}$ & $\begin{array}{l}\text { Copper+ } \\
\text { Mancozeb }\end{array}$ & $41 \mathrm{WP}$ & Syngenta \\
\hline 3 & $\begin{array}{l}\text { Dithane } \\
\text { M-45 }\end{array}$ & Mancozeb & $80 \mathrm{WP}$ & $\begin{array}{l}\text { Rohm \& } \\
\text { Hass Ltd }\end{array}$ \\
\hline 4 & Derosal & Carbendazim & $50 \mathrm{WP}$ & $\begin{array}{l}\text { Bayer (Pvt) } \\
\text { Ltd. }\end{array}$ \\
\hline 5 & Captan & Captan & $50 \mathrm{WP}$ & ICI (Pvt) Ltd. \\
\hline 6 & Benlate & Benomyl & $50 \mathrm{WP}$ & Du Pont \\
\hline 7 & $\begin{array}{l}\text { Ridomil } \\
\text { Gold }\end{array}$ & $\begin{array}{l}\text { Matalaxyl+ } \\
\text { Mancozeb }\end{array}$ & $68 \mathrm{WP}$ & Syngenta \\
\hline 8 & Cobox & $\begin{array}{l}\text { Copper } \\
\text { oxychloride }\end{array}$ & $50 \mathrm{WP}$ & Pak Agro \\
\hline 9 & Daconil & Chlorothalonil & $75 \mathrm{WP}$ & Syngenta \\
\hline
\end{tabular}

\section{In vitro evaluation of fungicides}

The effectiveness of nine fungicides was tested by using poisoned food technique (Nene and Thapliyal, 1982). Requisite quantity of active ingredient of each fungicide was mixed in autoclaved PDA to obtain the required concentrations of 50,100 and $150 \mathrm{ppm}$. Poisoned 
medium was then poured into each sterilized 90-mm-dia. sterilized petriplate, allowed to solidify and proceeded as described above.

\section{Pot culture assay}

For testing the affectivity of fungicides against $M$. phaseolina (MP-7) in pots, surface sterilized seeds each of green gram (NM-92) and black gram (Mash-98) were treated with 1, 2 and $3 \mathrm{~g}$ of a.i of each fungicide as slurry method. Control seeds were treated with sterile distilled water. Ten seeds in five replications were sown in sterile pots containing a mixture of soil and sand at the rate of 1 : 1 (v: v) amended with the rice seeds colonized with $M$. phaseolina@2g/kg soil. The pots were kept in growth rooms at $30{ }^{\circ} \mathrm{C}$. Data on percentage germination/plant survival was recorded after 20 days.

\section{Statistical analysis}

The experiments were conducted twice. Percent reduction in mycelial growth and increase in seedling emergence were calculated over controls prior to statistical analysis (Hussain et al., 2016; Kayani et al., 2018). All the data were subjected to Analysis of Variance (ANOVA) using GenStat package 2009, (12 ${ }^{\text {th }}$ edition) version 12.1.0.3278 (www.vsni.co.uk). The differences among means were compared by Fisher's Protected Least Significant Difference Test at $(\mathrm{P} \leq 0.05)$. No significant interaction was observed between the data of both the experiments, so the two sets of data were combined for analysis. Standard errors of differences of means were calculated in Microsoft Excel 2007.

\section{RESULTS}

\section{Radial growth of M. phaseolina}

Highly significant inhibitory effects of fungicides (F $=380.04 ; \mathrm{df}=8,18 ; \mathrm{P}<0.001)$ and their concentrations $(\mathrm{F}$ $=594.69 ; \mathrm{df}=2,36 ; \mathrm{P}<0.001)$ were recorded on the growth of $M$. phaseolina. The interaction between fungicides and their concentrations was also found to be highly significant $(\mathrm{F}=13.09 ; \mathrm{df}=16,36 ; \mathrm{P}<0.001)$.

All the fungicides caused significant inhibition of the fungus over control. Maximum individual inhibition of growth of the fungus was recorded with Benomyl (83.89\%) followed by Carbendazim (79.11\%) at a concentration of $150 \mathrm{ppm}$. Copper oxychloride at a concentration of $50 \mathrm{ppm}$ gave the minimum inhibition $(12.50 \%)$. The individual inhibitions caused by the fungicides are given in the Table II. Concentrations also had significant inhibitory effects on the growth of the fungus. All the fungicides caused maximum inhibition of the growth of the fungus at a concentration of $150 \mathrm{ppm}$.
With a decrease in the concentration, the inhibition in the growth also decreased. The inhibition of growth was found to be directly proportional to the concentration.

Table II: In vitro radial growth inhibition of $M$. Phaseolina by fungicides .

\begin{tabular}{lllll}
\hline \multirow{2}{*}{ Fungicide } & \multicolumn{4}{c}{ \% growth inhibition at } \\
\cline { 2 - 5 } & $50 \mathrm{ppm}$ & $100 \mathrm{ppm}$ & $150 \mathrm{ppm}$ & Average \\
\hline Propineb & $41.11 \pm$ & $50.33 \pm$ & $61.44 \pm$ & 50.96 \\
& 1.61 & 1.88 & 1.36 & \\
Copper+ & $8.33 \pm$ & $26.11 \pm$ & $53.56 \pm$ & 29.33 \\
Mancozeb & 1.26 & 1.80 & 1.17 & \\
& & & & \\
Mancozeb & $21.44 \pm$ & $30.89 \pm$ & $56.11 \pm$ & 36.15 \\
& 0.60 & 1.01 & 1.15 & \\
Carbendazim & $63.33 \pm$ & $73.00 \pm$ & $79.11 \pm$ & 71.81 \\
& 1.61 & 1.30 & 1.30 & \\
Captan & $19.22 \pm$ & $31.67 \pm$ & $41.44 \pm$ & 30.78 \\
& 2.17 & 1.04 & 1.17 & \\
Benomyl & $66.89 \pm$ & $78.67 \pm$ & $83.89 \pm$ & 76.48 \\
& 1.45 & 1.59 & 1.15 & \\
Meatalaxyl+ & $42.56 \pm$ & $51.44 \pm$ & $57.78 \pm$ & 50.59 \\
Mancozeb & 1.01 & 1.45 & 0.87 & \\
Copper & $12.56 \pm$ & $23.89 \pm$ & $34.22 \pm$ & 23.56 \\
oxychloride & 0.93 & 0.00 & 1.01 & \\
Chlorothalonil & $25.89 \pm$ & $34.44 \pm$ & $53.33 \pm$ & 37.89 \\
& 1.30 & 1.44 & 2.75 & \\
\hline
\end{tabular}

Values are the means of the five replicate samples. Figures following \pm are standard errors

Plant survival of green gram and black gram

Fungicides also affected significantly the plant survival of green gram $(\mathrm{F}=13.76 ; \mathrm{df}=8,18 ; \mathrm{P}<0.001)$ and black gram $(\mathrm{F}=27.62 ; \mathrm{df}=8,18 ; \mathrm{P}<0.001)$ over control. Maximum plant survival was observed where the seeds were treated with Benomyl followed by Carbendazim. However, Copper + Mancozeb and Copper oxychloride treated seeds gave the minimum germination and survival of plants. Doses also had a significant effect on the germination and plant survival. Maximum germination and survival was recorded where the seeds were treated with a concentration of $150 \mathrm{ppm}$ and minimum was recorded in case of $50 \mathrm{ppm}$ concentration. With a decrease in the concentration, the germination and survival decreased significantly showing a direct relationship between concentrations and plant survival. Benomyl at $150 \mathrm{ppm}$ concentration showed the highest rate of plant survival of 76.67\% whereas Carbendazim and Propineb with same 
concentration exhibited 66.67 and $63.33 \%$ plant survival respectively. Other fungicides also showed enhanced effect at $150 \mathrm{ppm}$ as compared to other concentrations but having minimum plant survival rate (40-56\%). Copper oxychloride remained behind in its effectiveness in terms of disease incidence and plant survival. The individual germinations and survivals of greem gram and black gram have been given in Tables III and IV, respectively.

Table III.- Effect of fungicides on plant survival of green gram against charcoal rot (M. phaseolina).

\begin{tabular}{lllll}
\hline \multirow{2}{*}{ Fungicide } & \multicolumn{4}{c}{ Plant survival at } \\
\cline { 2 - 5 } & $50 \mathrm{ppm}$ & $100 \mathrm{ppm}$ & $150 \mathrm{ppm}$ & Average \\
\hline Propineb & $43.33 \pm$ & $50.00 \pm$ & $63.33 \pm$ & 52.22 \\
& 0.33 & 0.58 & 0.33 & \\
Copper+ & $26.67 \pm$ & $33.33 \pm$ & $43.33 \pm$ & 34.44 \\
Mancozeb & 0.33 & 0.33 & 0.33 & \\
Mancozeb & $30.00 \pm$ & $36.67 \pm$ & $46.67 \pm$ & 37.78 \\
& 0.00 & 0.33 & 0.33 & \\
Carbendazim & $46.67 \pm$ & $53.33 \pm$ & $66.67 \pm$ & 55.56 \\
& 0.33 & 0.33 & 0.33 & \\
Captan & $30.00 \pm$ & $36.67 \pm$ & $46.67 \pm$ & 37.78 \\
& 0.58 & 0.33 & 0.33 & \\
Benomyl & $50.00 \pm$ & $56.67 \pm$ & $76.67 \pm$ & 61.11 \\
& 0.00 & 0.33 & 0.33 & \\
Meatalaxyl + & $43.33 \pm$ & $50.00 \pm$ & $56.67 \pm$ & 50.00 \\
Mancozeb & 0.33 & 0.00 & 0.33 & \\
Copper & $26.67 \pm$ & $33.33 \pm$ & $46.67 \pm$ & 35.56 \\
oxychloride & 0.33 & 0.33 & 0.33 & \\
Chlorothalonil & $40.00 \pm$ & $46.67 \pm$ & $56.67 \pm$ & 47.78 \\
& 0.00 & 0.33 & 0.33 & \\
\hline
\end{tabular}

Values are the means of the five replicate samples. Figures following \pm are standard errors

\section{DISCUSSION}

Charcoal rot caused by M. phaseolina is one of the most important diseases of pulses incurring heavy yield losses. No fungicides have been registered in Pakistan to combat this disease. Therefore, in the present studies, nine fungicides registered for other soil borne pathogens were tested for their effectiveness against the fungus. Of all the fungicides, Benomy and Carbendazim proved to be the most effective. Benomyl has successfully controlled many diseases of different crops as leaf spot in sugar beet (Kalaoglanidis et al., 2003), rice blast (Kamerwar, 1976), scab and powdery mildew of apples, cucurbits and strawberries (Scot et al., 1979). Marley and Genga
(2004) found that benomyl reduced the mycelial growth of Stenocarpella maydis in vitro. It also inhibited the growth of Fusarium oxysporum (El-Tobshy et al., 1981). Mamza et al. (2010) reported that benomyl along with thiram and tricyclazole suppressed growth of $F$. pallideroseum isolated from castor. Khan and Khan (2006) found that both benomyl and carbendazim inhibited 100\% mycelial growth of $M$. phaseolina. Carbendazim also inhibited the growth and sclerotial production of $M$. phaseolina (Suryawashi et al., 2008). Similarly, seed dressing with fungicides enhanced seedling emergence and reduced mortality rate in legumes (Muthomi et al., 2007).

Table IV.- Effect of fungicides on plant survival of black gram against charcoal rot (M. phaseolina).

\begin{tabular}{lllll}
\hline \multirow{2}{*}{ Fungicides } & \multicolumn{4}{c}{ Plant survival at } \\
\cline { 2 - 5 } & $50 \mathrm{ppm}$ & $100 \mathrm{ppm}$ & $150 \mathrm{ppm}$ & Average \\
\hline Propineb & $40.33 \pm$ & $50.00 \pm$ & $63.33 \pm$ & 51.22 \\
& 0.00 & 0.58 & 0.33 & \\
Copper+Man- & $20.00 \pm$ & $33.33 \pm$ & $43.33 \pm$ & 32.22 \\
cozeb & 0.00 & 0.33 & 0.33 & \\
Mancozeb & $23.33 \pm$ & $36.67 \pm$ & $46.67 \pm$ & 35.56 \\
& 0.33 & 0.33 & 0.33 & \\
Carbendazim & $43.33 \pm$ & $53.33 \pm$ & $66.67 \pm$ & 54.44 \\
& 0.33 & 0.33 & 0.33 & \\
Captan & $26.67 \pm$ & $36.67 \pm$ & $46.67 \pm$ & 36.67 \\
& 0.33 & 0.33 & 0.33 & \\
Benomyl & $46.67 \pm$ & $56.67 \pm$ & $76.67 \pm$ & 60.00 \\
& 0.33 & 0.33 & 0.33 & \\
Meatalax- & $36.67 \pm$ & $50.00 \pm$ & $56.67 \pm$ & 47.78 \\
yl+Mancozeb & 0.33 & 0.00 & 0.33 & \\
Copper oxychlo- & $20.00 \pm$ & $33.33 \pm$ & $46.67 \pm$ & 33.33 \\
ride & 0.00 & 0.33 & 0.33 & \\
Chlorothalonil & $33.33 \pm$ & $46.67 \pm$ & $56.67 \pm$ & 45.56 \\
& 0.33 & 0.33 & 0.33 & \\
\hline
\end{tabular}

Values are the means of the five replicate samples. Figures following \pm are standard errors

A number of mechanisms are involved in the suppression and inhibition of pathogens by fungicides. It was found from the present investigation that fungicides significantly caused reduction in growth of M. phaseolina and enhanced germination of green gram and black gram. Fungicides act by binding with b-tubulin polymers of pathogens which play a key role in nuclear division and result in inhibition of polymerizing activity of microtubules. These also cause hindrance in different regulatory cellular activities including mitosis, meiosis and cell shape maintenance etc. (Nene and Thapliyal, 
1993). Similarly, Carbendazim inactivates tubulin function of pathogen necessary for their maintenance and growth (Butlers et al., 1995).

\section{CONCLUSION}

It is concluded from the present studies that fungicides registered for other soil borne pathogens can be effectively used against the charcoal rot causing fungus Macrophomina phaseolina. As Benomyl, Carbendazim, Propineb and Meatalaxyl+Mancozeb proved to be the effective against the fungus and hence recommended for the control of charcoal rot in Pakistan.

Statement of conflict of interest

Authors have declares that there is no conflict.

\section{REFERENCES}

Abawi, G.S. and Pastor-Corrales, M.A., 1990. Root rots of beans in Latin America and Africa: diagnosis, research methodologies and management strategies. CIAT, Colombia.

Anonymous, 2011. Agricultural statistics of Pakistan, Ministry of Food, Agriculture and Live Stock, Agriculture and Livestock Division, Islamabad, Pakistan.

Ashfaq, M., Saleem, A., Waqas, M. and Mukhtar, T., 2017. Natural occurrence and host range studies of cucumber mosaic virus (CMV) infecting ornamental species in the Rawalpindi-Islamabad area of Pakistan. Philipp. Agric. Scient., 100: 5561.

Aslam, M.N., Mukhtar, T., Ashfaq, M. and Hussain, M.A., 2017a. Evaluation of chili germplasm for resistance to bacterial wilt caused by Ralstonia solanacearum. Australas. Pl. Pathol., 46: 289-292 https://doi.org/10.1007/s13313-017-0491-2

Aslam, M.N., Mukhtar, T., Hussain, M.A. and Raheel, M., 2017b. Assessment of resistance to bacterial wilt incited by Ralstonia solanacearum in tomato germplasm. J. Pl. Dis. Prot., 124: 585-590. https:// doi.org/10.1007/s41348-017-0100-1

Aslam, M.A., Javed, K., Javed, H., Mukhtar, T. and Bashir, M.S., 2019a. Infestation of Helicoverpa armigera Hübner (Noctuidae: Lepidoptera) on soybean cultivars in Pothwar region and relationship with physico-morphic characters. Pak. J. agric. Sci., 55: 401-405.

Aslam, M.N., Mukhtar, T., Jamil, M. and Nafees, M., 2019b. Analysis of aubergine germplasm for resistance sources to bacterial wilt incited by
Ralstonia solanacearum. Pak. J. agri. Sci., 56: 119-122.

Barnett, H.L. and Hunter, B.B., 1972. Illustrated genera of imperfect fungi. Burgress Publishing Company, Minneapolis MN, pp. 241.

Bashir, M.A. and Malik, B.A., 1988. Diseases of major pulse crops in Pakistan. Trop. Pest Manage., 34:309314. https://doi.org/10.1080/09670878809371262

Butlers, J.A., Kendall, S.J., Wheeler, I.E. and Hollomon, D.W., 1995. Tubulins: Lessons from existing products that can be applied to target new antifungals. In: Antifungal agents, discovery and mode of actions (eds. G.K. Dixon, L.G. Copping, D.W. Howwomon), BIOS, Oxford. pp. 173-191.

Charles, Y.Y., 1978. Mungbean diseases and control. Proceedings of the $1^{\text {st }}$ International Mungbean Symposium, AVRDC.

Cottingham, C., 1981. Numbers and distribution of sclerotia of Macrophomina phaseolina in soils of South Carolina. Pl. Dis. Rep., 65: 355-356. https:// doi.org/10.1094/PD-65-355

Dhingra, O.D. and Chagas, D., 1981. Effect of soil temperature, moisture and nitrogen on competitive saprophytic ability of Macrophomina phaseolina. Trans. Br. Mycol. Soc., 77: 15-20. https://doi. org/10.1016/S0007-1536(81)80173-8

El-Tobshy, Z.M., El-Sayed, E.I., Sattar, M.A. and Rahman, A., 1981. Studies on the control of damping off and root rot diseases of Egyptian clover. Res. Bull. No., 178. Faculty of Agriculture, Ain Shams University, pp. 11.

Fateh, F.S., Mukhtar, T., Kazmi, M.R., Abbassi, N.A. and Arif, A.M., 2017. Prevalence of citrus decline in district Sargodha. Pak. J. agric. Sci., 54: 9-13. https://doi.org/10.21162/PAKJAS/17.5643

Hoes, J.A., 1985. Macrophomina phaseolina causal agent of charcoal rot of sunflower and other crops. Agricultural Canada Research Statistics, Modern Manitoba.

Hussain, M.A., Mukhtar, T. and Kayani, M.Z., 2016. Reproduction of Meloidogyne incognita on resistant and susceptible okra cultivars. Pak. J. agric. Sci., 53(2): 371-375. https://doi.org/10.21162/ PAKJAS/16.4175

Iqbal, U. and Mukhtar, T., 2014. Morphological and pathogenic variability among Macrophomina phaseolina isolates associated with mungbean (Vigna radiata L.) Wilczek from Pakistan. Sci. World J., Article ID 950175, 9 pages. https://doi. org/10.1155/2014/950175

Iqbal, U., Mukhtar, T. and Iqbal, S.M., 2014. In vitro and in vivo evaluation of antifungal activities of some 
antagonistic plants against charcoal rot causing fungus, Macrophomina phaseolina. Pak. J. agric. Sci., 51(3): 691-696.

Javed, H., Hussain, S.S., Javed, K., Mukhtar, T. and Abbasi, N.A., 2017a. Comparative infestation of brinjal stem borer (Euzophera perticella) on six aubergine cultivars and correlation with some morphological characters. Pak. J. agric. Sci., 54: 753-758.

Javed, H., Mukhtar, T., Javed, K. and Ata ul Mohsin, 2017b. Management of eggplant shoot and fruit borer (Leucinodes orbonalis Guenee) by integrating different non-chemical approaches. Pak. J. agric. Sci., 54: 65-70. https://doi.org/10.21162/ PAKJAS/ 17.5282

Kamerwar, R., 1976. Efficacy of organic fungicides for the control of rice blast. Pesticides, 10: 25-29.

Karaoglanidis, G.S., Karadimos, D.A., Ioannidis, P.M. and Ioannidis, P.I., 2003. Sensitivity of Cercospora beticola populations to Fentinacetate, Benomyl and Flutriatol in Greece. Crop Prot., 22: 735-740. https://doi.org/10.1016/S0261-2194(03)00036-X

Kayani, M.Z. and Mukhtar, T., 2018. Reproductivity of Meloidogyne incognita on fifteen cucumber cultivars. Pakistan J. Zool., 50: 1717-1722. https:// doi.org/10.17582/journal.pjz/2018.50.5.1717.1722

Kayani, M.Z., Mukhtar, T. and Hussain, M.A., 2017. Effects of southern root knot nematode population densities and plant age on growth and yield parameters of cucumber. Crop Prot., 92: 207-212. https://doi.org/10.1016/j.cropro.2016.09.007

Kayani, M.Z., Mukhtar, T. and Hussain, M.A., 2018. Interaction between nematode inoculum density and plant age on growth and yield of cucumber and reproduction of Meloidogyne incognita. Pakistan J. Zool., 50: 897-902. https://doi.org/10.17582/ journal.pjz/2018.50.3.897.902

Khan, A.A. and Khan, R.U., 2006. Management of Macrophomina leaf spot of Vigna radiata by fungicides. Ann. Pl. Prot. Sci., 14: 258-259.

Khan, A.R., Javed, N., Sahi, S.T., Mukhtar, T., Khan, S.A. and Ashraf, W., 2017. Glomus mosseae (Gerd \& Trappe) and neemex reduce invasion and development of Meloidogyne incognita. Pakistan J. Zool., 49: 841-847. https://doi.org/10.17582/ journal.pjz/2017.49.3.841.847

Malik, B.A., 1994. Grain legumes, crop production. National Book Foundation, Islamabad. pp. 301.

Mamza, W.S., Zarafi, A.B. and Alabi, O., 2010. In vitro evaluaion of six fungicides on radial mycelial growth and regrowth of Fusarium pallidoroseum isolated from castor (Ricinus communis) in Samaru, Nigeria. Arch. Phytopathol. Pl. Prot., 43: 116-122. https://doi. org/10.1080/03235400701806401

Marley, P.S. and Gbenga, O., 2004. Fungicide control of Stenocarpella maydis in the Nigerian Savanna. Arch. Phytopathol. Pl. Prot., 37: 19-28. https://doi. org/10.1080/03235400310001631936

Meyer, W.A., Sinclair, J.B. and Khare, M.N., 1973. Biology of Macrophomina phaseolina in soil studies with selective media. Phytopathology, 63: 613-620. https://doi.org/10.1094/Phyto-63-613

Mukhtar, T., Arooj, M., Ashfaq, M. and Gulzar, A., 2017a. Resistance evaluation and host status of selected green gram germplasm against Meloidogyne incognita. Crop Prot., 92: 198-202. https://doi.org/10.1016/j.cropro.2016.10.004

Mukhtar, T., Hussain, M.A. and Kayani, M.Z., 2017b. Yield responses of 12 okra cultivars to southern root-knot nematode (Meloidogyne incognita). Bragantia, 76: 108-112. https://doi. org/10.1590/1678-4499.005

Mukhtar, T., Jabbar, A., Raja, M.U. and Javed, H., 2018. Re-emergence of wheat seed gall nematode (Anguina tritici) in Punjab, Pakistan. Pakistan J. Zool., 50: 1195-1198. https://doi.org/10.17582/ journal.pjz/2018.50.3.sc4

Mukhtar, T., 2018. Management of root-knot nematode, Meloidogyne incognita, in tomato with two Trichoderma species. Pakistan J. Zool., 50: 1589-1592. https://doi.org/10.17582/journal. pjz/2018.50.4.sc15

Muthomi, J.W., Otieno, P.E., Chemining'wa, G.N., Nderitu, J.H. and Wagacha, J.M., 2007. Effect of legume root rot pathogens and fungicide seed treatment on nodulation and biomass accumulation. J. biol. Sci., 7: 1163-1170. https://doi.org/10.3923/ jbs.2007.1163.1170

Nene, Y.L. and Thapliyal, P.N., 1982. Fungicides in plant disease control. Oxford and IBH Publishing Company, New Delhi, 507 pp.

Scot, D.H., Draper, A.D. and Maos, J.I., 1979. Benomyl for control of powdery mildew on strawberry plants in greenhouse. Pl. Dis. Rept., 54: 362-363.

Sinclair, J.B., 1982. Compendium of soybean diseases. American Phytopathological Society, Saint Paul,Minn, USA, $2^{\text {nd }}$ edition.

Suryawanshi, V.P., Hajare, S.T., Karnewar, S.D. and Kamble, N.S., 2008. In-vitro chemical and biological control of Macrophomina phaseolina on black gram. J. Soils Crop., 18: 375-378.

Tariq-Khan, M., Munir, A., Mukhtar, T., Hallmann, J. and Heuer, H., 2017. Distribution of root-knot 
nematode species and their virulence on vegetables in northern temperate agro-ecosystems of the Pakistani-administered territories of Azad Jammu and Kashmir. J. Pl. Dis. Prot., 124: 201-212. https://doi.org/10.1007/s41348-016-0045-9

Wheeler, H., 1975. Plant pathogenesis. Academic press, London, UK. https://doi.org/10.1007/978-3642-66184-6 